\title{
Critical Elements in Fly Ash from the Combustion of Bituminous Coal in Major Polish Power Plants
}

\author{
Barbara Bielowicz ${ }^{1, *}$, Dariusz Botor $^{1}$, Jacek Misiak ${ }^{1}$, and Marian Wagner $^{1}$ \\ ${ }^{1}$ AGH University of Science and Technology, Faculty of Geology, Geophysics and Environmental \\ Protection, A. Mickiewicza Av. 30, 30-059 Krakow, Poland
}

\begin{abstract}
The concentration of critical elements, including such REE as $\mathrm{Fe}, \mathrm{Co}, \mathrm{W}, \mathrm{Zn}, \mathrm{Cr}, \mathrm{Ni}, \mathrm{V}, \mathrm{Mn}, \mathrm{Ti}, \mathrm{Ag}, \mathrm{Ga}, \mathrm{Ta}, \mathrm{Sr}, \mathrm{Li}$, and $\mathrm{Cu}$, in the so-called fly ash obtained from the 9 Polish power plants and 1 thermal power station has been determined. The obtained values, compared with the global average concentration in bituminous coal ash and sedimentary rocks (Clarke values), have shown that the enrichment of fly ash in the specified elements takes place in only a few bituminous coal processing sites in Poland. The enrichment factor (EF) is only slightly higher (the same order of magnitude) than the Clarke values. The enrichment factor in relation to the Clarke value in the Earth's crust reached values above 10 in all of the examined ashes for the following elements: $\mathrm{Cr}, \mathrm{Ni}, \mathrm{V}, \mathrm{W}$, and, in some ash samples, also $\mathrm{Cu}$ and $\mathrm{Zn}$. The obtained values are low, only slightly higher than the global average concentrations in sedimentary rocks and bituminous coal ashes. The ferromagnetic grains (microspheres) found in bituminous coal fly ashes seem to be the most economically prospective in recovery of selected critical elements. The microanalysis has shown that iron cenospheres and plerospheres in fly ash contain, in addition to enamel and iron oxides (magnetite and hematite), iron spinels enriched in $\mathrm{Co}, \mathrm{Cr}, \mathrm{Cu}, \mathrm{Mn}, \mathrm{Ni}, \mathrm{W}$, and $\mathrm{Zn}$. Key words - Critical Elements, Rare earth elements; Coal fly ash.
\end{abstract}

\section{Introduction}

Bituminous coal ash is characterized by a significantly higher concentration of critical elements than ash from burning of other solid fossil fuels [1,2,3, and 4] and can be a potential source of critical raw materials. This is incombustible component of coal resulted in combustion processes in professional power plants and combined heat and power plants (CHP). The paper is focused on examining coal ashes from the currently exploited Polish deposits. Special attention is paid to the so-called fly ash, which are ash components collected by electrostatic precipitators. These ashes are characterized by multiphase composition, which depends mainly on the petrographic composition of coal subjected to the combustion technology.

* Corresponding author: bbiel@ agh.edu.pl 


\section{Research methodology}

The geochemical and petrographic analysis of fly ash from Polish power plants and heat plants (14 samples) collected from ash storage sites at bituminous coal-fired power plants was carried out. The samples were collected at the following power plants: Skawina, Siersza, Połaniec, Kozienice, Jaworzno (2 samples), Ostrołęka, Poznań, Opole (3 samples), Dolna Odra (2 samples), and the Janikowo thermal power station (Fig. 1).

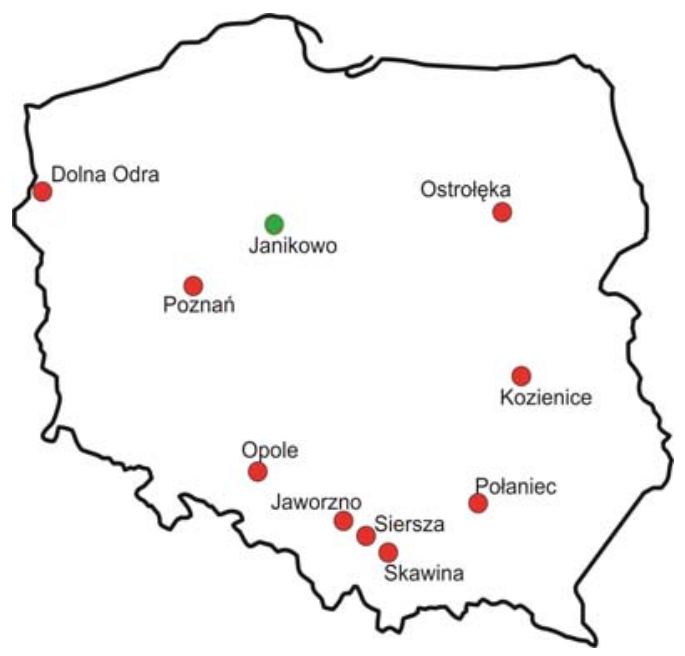

Fig. 1. Location of power plants (red) and thermal power stations (green) from which the analyzed ash samples were collected

The determination of chemical composition (the presence of minor, trace, and rare elements) was carried out at the Acme Labs (Canada) using inductively coupled plasma mass spectrometry (ICP-MS) A total of 53 elements, including most of the critical elements were determined.

Petrographic examination using an ZEISS reflected light optical microscope, a JEOL JXA-8230 SuperProbe Electron Probe Microanalyzer, and the WDS microanalysis of chemical composition of solids were carried out at the AGH UST - KGHM Polska Miedź SA Laboratory of Critical Elements of Critical Elements Laboratory of the Faculty of Geology, Geophysics and Environmental Protection at the AGH University of Science and Technology in Kraków. A total of 10 samples of fly ash were examined. Selected samples with the highest content of critical elements and those containing microspheres were selected for the analysis. The samples were covered with graphite before the analysis. The qualitative microanalysis of elemental composition (from boron to uranium) was performed using a wavelength-dispersive X-ray spectroscopy spectrometer. The quantitative analysis of elemental composition was performed using an X-ray diffraction (WDS) spectrometer. The images of measurement points were obtained using the secondary electrons (SE). The WDS analysis was performed only for microspheres with a current of $20 \mathrm{nA}$ and an accelerating voltage of $15 \mathrm{kV}$.

\section{Results and discussion}

\subsection{The petrographic analysis of fly ash}

During industrial combustion of coal (at temperatures of up to ca. $1400^{\circ} \mathrm{C}$ ), its mineral matter is being liquefied and simultaneously subjected to complex physicochemical changes involving 
dehydroxylation of hydrated aluminosilicates and aluminum silicates, partial mullitization, carbonate decomposition, iron sulphide breakdown and reduction [5]. Rapid cooling of combustion products promotes the formation of amorphous (non-crystalline) particles, often of a spherical shape - microspheres. Gases trapped inside them can expand and create the so-called cenospheres and plerospheres [5] (Fig. 2). Minerals with a high melting point usually remain relatively unchanged [6].

A

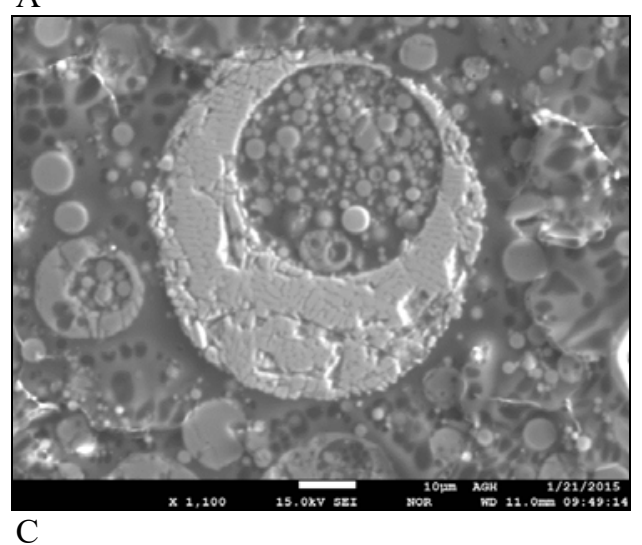

$\mathrm{C}$

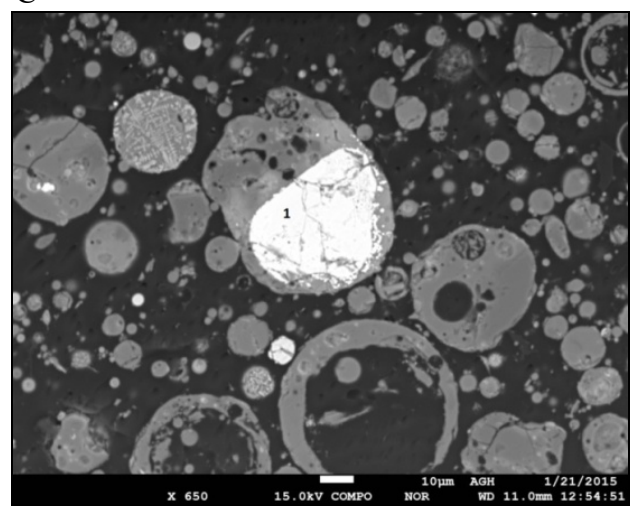

E

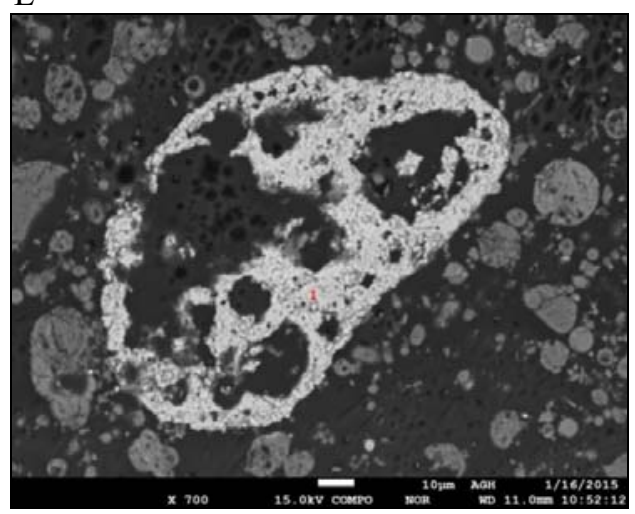

B

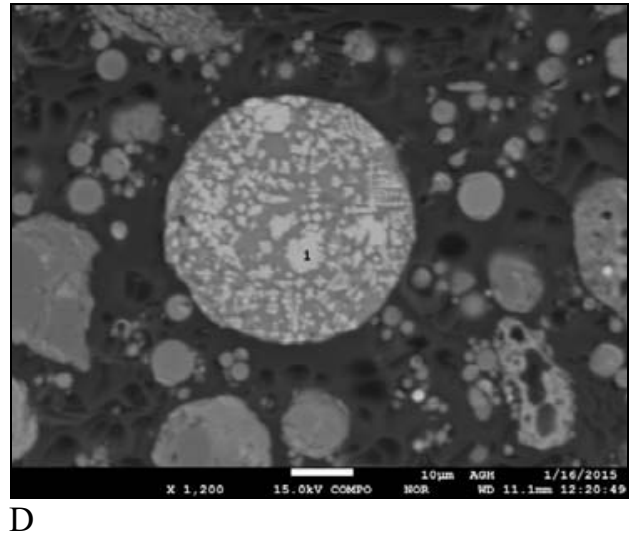

D

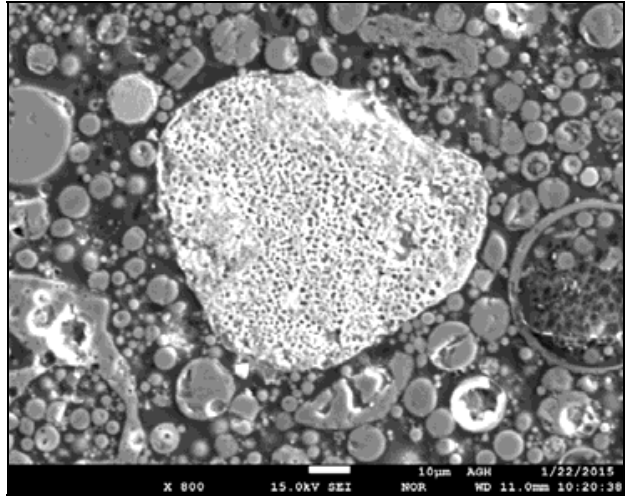

$\mathrm{F}$

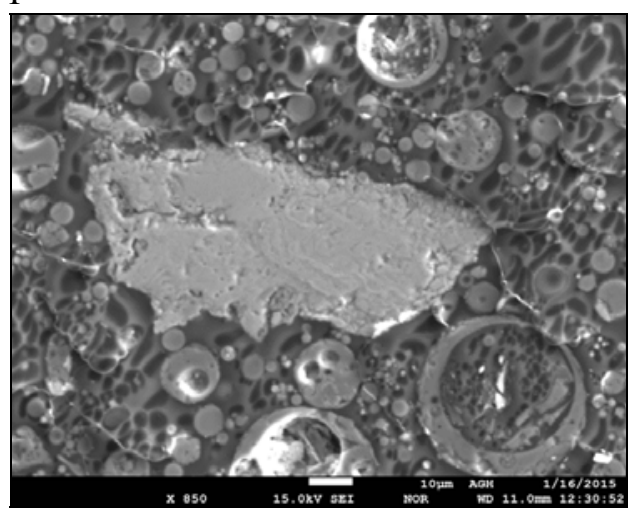

Fig. 2. A) Hematite crassisphere (Dolna Odra power plant), B) Hematite plerosphere with aluminosilicates (spinel) (Siersza power plant), C) Various forms of microspheres, the central filled with zircon (lighter) (Poznań power plant), D) Porous hematite (Opole power plant), E) Hematite crassisphere (Skawina power plant), F) Irregular iron oxide grain (Siersza power plant) 
There are two types of microspheres [7]: "empty balls" in which the hollows are filled with gas and the so-called cenospheres and plerospheres, in which the empty spaces (voids) are filled with other mineral particles, most commonly in the spongy (porous) form. The term cenosphere is derived from Greek: kenos + sphere - hollow sphere, while plerosphere from Greek: plërës + sphere - filled sphere [8].

In the examined fly ash resulting from the combustion of bituminous coals from 9 power and 1 thermal power station the occurrence of microparticles belonging to the silicates and aluminosilicates (quartz, mullite, and silicate enamel), iron oxides, carbonates, and unburned organic matter has been confirmed.

The ferromagnetic grains (microspheres), found in the following concentrations in the samples: Skawina (sample no. 2) $-0.16 \%$, Siersza (3) $-0.31 \%$, Połaniec (5) $-0.18 \%$, Kozienice (6) - 0.22\%, Jaworzno (7) $-0.17 \%$, Janikowo (8) $-0.16 \%$, Ostrołęka (10) $-0.08 \%$, Poznań (13) $-0.29 \%$, Opole (16) $-0.24 \%$, and Dolna Odra (17) $-0.38 \%$. Based on the literature, it can be stated that microspheres are promising in analyzing the occurrence of critical elements $[5,8]$.

Iron microspheres are highly variable in terms of both size and morphology. The size of cenospheres and plerospheres ranges from a few to several dozen micrometers (Fig. 1). Cenospheres can have very thin (tenuisphere) or thick walls (crassisphere), in which case they usually show secondary porosity within the walls. The spherical objects (plerospheres) are partially filled with porous magnetite-hematite aggregates, where lighter hematite lamellae are clearly visible against the background of the darker magnetite. Some of the plerospheres are fully filled with magnetite containing fine (lighter) hematite lamellae. In addition, plerospheres filled with enamel (of dark gray color) containing magnetite grains in different geometrical forms have also been found (Fig. 2C). In some cases, magnetite in the enamel filling the microspheres forms various dendritic-skeletal forms (Fig. 2B). In addition, magnetitehematite aggregates filling the gaps in the enamel have also been shown in the examined samples.

\subsection{The chemical analysis of ashes}

\subsubsection{The chemical composition of ash}

The main chemical components in the examined ash include $\mathrm{SiO}_{2}(30.01-52.72 \mathrm{wt} \%)$ and $\mathrm{Al}_{2} \mathrm{O}_{3}(9.97-29.02 \mathrm{wt} \%)$. There are also $\mathrm{CaO}(2.13-45.20 \mathrm{wt} \%), \mathrm{Fe}_{2} \mathrm{O}_{3}(3.28-8.15$ wt \%), $\mathrm{MgO}\left(1.57-2.97\right.$ wt \%), $\mathrm{Na}_{2} \mathrm{O}\left(0.40-2.14\right.$ wt \%), $\mathrm{K}_{2} \mathrm{O}\left(1.32-3.5\right.$ wt \%), $\mathrm{P}_{2} \mathrm{O}_{5}(0.16-0.83$ wt \%), $\mathrm{TiO}_{2}\left(0.48-1.27\right.$ wt \%), MnO (0.05-0.11 wt \%), and $\mathrm{Cr}_{2} \mathrm{O}_{3}(0.012-0.030$ wt \%). Most of the examined ash samples is silica-dominated; the only exceptions are the ash samples from Janikowo (sample no. 8) and Ostrołęa (sample 10), which are calcium-dominated. The chemical composition of ash indicates the origin of coal burned in power plants (calciumdominated ash is typical for coal from the Paralic series, while silica-dominated for coal from the limnic-fluvial series) [9].

\subsubsection{Critical elements}

The measured levels of critical elements were compared with the so-called Clarke value in sedimentary rocks (the global average content of a specified element in sedimentary rocks) [10] and the Clarke value in bituminous coal ash, that is the global average for this raw material [2]. The Clarke value in sedimentary rocks is a good indicator of the concentration of certain chemical element due to the genetic affiliation of coal deposits to sedimentary rocks and the apparent association of this element with the shale-like concentration pattern in the Earth's crust [11]. Coal ashes usually contain higher amounts of critical elements 
when compared to coal $[1,2,4,12]$, which is a consequence of the combustion of organic matter; however, they are strongly modified by the so-called coefficient of volatility [13].

An analysis of the potential enrichment of the examined ashes was carried out by calculating the so-called Enrichment Factor (EF) as the ratio of the content of the element and the Clarke value. This coefficient is given in two variants: EF1 (mean value) and EF2 (max. value). Both factors are used for determining the content of critical elements in the examined fly ash samples in relation to the Clarke value in bituminous coal ash [2]. For a more complete analysis of the presence of critical elements in the fly ash, two other factors determining the concentration of selected elements (EF3 and EF4) referring to the Clarke value in sedimentary rocks, were used Ronov et al. [10] The EF3 value refers to the mean while the EF4 to the maximum value. The EF1 factors are low (generally lower than 1) while higher values of the EF2 factor can be observed for Be and B in the ash sample from Siersza and $\mathrm{Mn}$ in the ash sample from Skawina. EF4 factors higher than 1 was determined for: $\mathrm{Cu}, \mathrm{Li}, \mathrm{Ga}, \mathrm{Sb}, \mathrm{W}, \mathrm{Mo}, \mathrm{Zn}, \mathrm{Ag}$, and $\mathrm{B}$ in the sample from the Siersza power plant and for $\mathrm{Ba}$ from the Skawina power plant sample.

The performed analysis has confirmed that only the fly ash from coal burned in the Siersza power plant (with the exception of Ba concentration from Skawina) shows the above-Clarke values for $\mathrm{Be}, \mathrm{Ga}, \mathrm{Sb}, \mathrm{W}, \mathrm{Mo}, \mathrm{V}, \mathrm{Zn}, \mathrm{Ag}, \mathrm{B}, \mathrm{Cu}$, and Li. Although these are above-Clarke values, they are low and without economic significance, as it is believed that only EF $>10$ values are economically viable. The analysis of the enrichment of fly ashes from Polish power plants and bituminous coal fired power plants in critical elements, based on enrichment factors, has unequivocally shown that the enrichment of bituminous coal and its ashes (including fly ash) in the specified elements takes place in only a few bituminous coal processing sites in Poland. These are small values with no economic significance.

\subsection{The characteristic of critical elements in iron microspheres of the examined fly ash samples using the WDS analysis}

The ferromagnetic grains (microspheres) found in bituminous coal fly ashes seem promising in the analysis of the occurrence of selected critical elements. The morphology of microspheres is highly variable (Fig. 2 A-F). The size of cenospheres and plerospheres ranges from a few to several dozen of micrometers. Cenospheres have walls of varying thickness (from 1 to 20 $\mu \mathrm{m})$. Plerospheres can be filled with magnetite-hematite aggregates (Fig. 2A). In addition, plerospheres filled with enamel (of dark gray color) containing magnetite grains have also been found. In addition, magnetite-hematite aggregates filling the gaps in the enamel have also been shown in the examined samples (Fig. 2B). Locally, microsphere enamel occurs with zircon (Fig. 2C). The microanalysis has shown that ashes, in addition to enamel of the cenosphere and plerosphere, also contain iron oxides and spinels which are locally enriched in $\mathrm{Cr}, \mathrm{Cu}, \mathrm{Mn}, \mathrm{Ni}, \mathrm{W}$, and $\mathrm{Zn}$. In the examined samples, the iron content is definitely greater than the Clarke value of this element in the Earth's crust (Table 1). The average concentration for all points in the studied samples is $32.7 \%$, with the Clarke value in the Earth's crust at $5.6 \%$. In sample no. 8 (from the Janikowo power plant), the above-Clarke concentrations of Mn, with a maximum of 9867 ppm (the Clarke value in the Earth's crust and bituminous coal ash is $950 \mathrm{ppm}$ and $430 \mathrm{ppm}$ [2], respectively), in microspheres were recorded. In all of the analyzed samples, the $\mathrm{Cr}$ concentrations are up to several times higher than their Clarke values. The average concentration in the examined iron oxides is $1735 \mathrm{ppm}$, while the Clarke value of coal ash is $120 \mathrm{ppm}$. However, such enrichment may be related to the chromium oxide used during the polishing of the preparations; hence, the obtained results should be interpreted with caution. The enrichment in $\mathrm{Cu}$ is observed in some of the analyzed objects. 


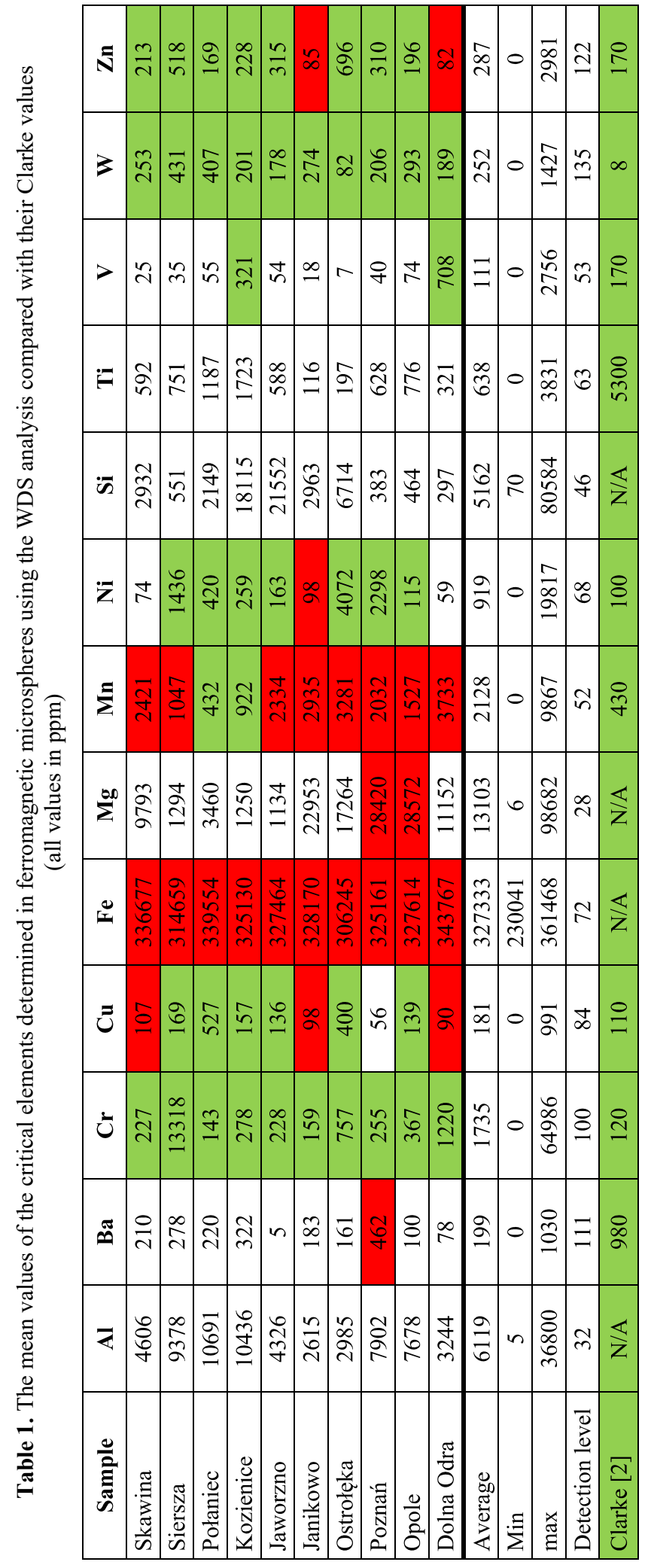


The highest values $(991 \mathrm{ppm})$ were measured in sample no. 10 from the Ostrołęka power plant in sample no. 5 from the Połaniec power plant, the $\mathrm{Cu}$ content of all tested grains was higher than the Clarke value in bituminous coal ash. In some of the analyzed samples, the Ni content was several times higher than the Clarke value in ash (100 ppm). The highest concentration of this element (19817 ppm) was recorded in sample no. 10 from the Ostrołęka power station. The average concentration of nickel for all analyzed samples is 919 ppm. Local enrichments in wolfram and zinc (their average concentration in the examined samples amounts to 252 and $287 \mathrm{ppm}$, while the Clarke value in the Earth's crust is $7.8 \mathrm{ppm}$ and $170 \mathrm{ppm}$, respectively) have also been confirmed [2]. Due to their strong magnetic properties, iron microspheres in fly ash seem to be relatively easy to separate. Each year, a total of 7.5 million $\mathrm{Mg}$ of fly ash are captured in Polish bituminous coal-fired power plants; hence, it is theoretically possible to obtain $0.6-2.9$ million tons of ferromagnetic aggregations from fly ash in order to recover the elements which concentration is higher than their Clarke value.

\section{Conclusions}

Fly ash samples from major Polish power plants and CHP plants were examined. The ashes contain cenospheres and plerospheres (spherical particles), in which voids are filled with other mineral particles, most commonly in the form of irregular aluminosilicate grains (mainly mullite), iron oxides, unburnt (fusained) coal particles, and spongy (porous) form. The content of iron microspheres in the examined ash ranges from 0.16 to $0.38 \%$ by volume, which has been confirmed by microscopic studies. The content of critical elements in iron microspheres contained in fly ash was examined using an electron microprobe (EDSWDS). The content of elements ranging from boron to uranium ( $\mathrm{Ta}, \mathrm{In}, \mathrm{V}, \mathrm{Ga}, \mathrm{Rh}, \mathrm{Nb}, \mathrm{Pd}$, $\mathrm{Pt}$, and $\mathrm{Cu}$ ) has been determined according to the apparatus settings. Microspheres of all the examined ash samples contain from 23.0 to $36.1 \%$ of $\mathrm{Fe}$, accompanied by numerous aboveclarke concentrations of critical elements, compared to the Clarke value in the earth's crust, including barium (up to 680, the Clarke value of $425 \mathrm{ppm}$ ), chromium (up to 3253, the Clarke value of $102 \mathrm{ppm}$ ), copper (up to 991, the Clarke value of $60 \mathrm{ppm}$, manganese (up to 9867, the Clarke value of $950 \mathrm{ppm}$ ), nickel (up to 19817, the Clarke value of $84 \mathrm{ppm}$ ), vanadium (up to 2756, the Clarke value of 120), wolfram (up to 1427, the Clarke value of $1,25 \mathrm{ppm}$ ), and zinc (up to 2981, the Clarke value of $70 \mathrm{ppm}$ ).

When compared to the Clarke value in the earth's crust, it is clearly visible that the concentration of elements in the ashes is highly variable; the most interesting are elements with the enrichment factor above 10 , including $\mathrm{Cr}, \mathrm{Ni}, \mathrm{V}, \mathrm{W}$, and, in some ash samples, $\mathrm{Cu}$ and $\mathrm{Zn}$.

The obtained results were also compared with the average values for bituminous coal ashes, determined on a global scale and expressed in the form of specific Clarke values of bituminous coal. These Clarke values are different than the Clarke values in the earth's crust and sedimentary rocks, while take into account the geochemical affinity between the individual critical elements and the $\mathrm{C}$ element and generally characterize the detailed geological processes involved in the formation of coal deposits.

The obtained values are low, only slightly higher (the same order of magnitude) than the global average concentrations in sedimentary rocks and bituminous coal ashes. The ferromagnetic grains (microspheres) found in bituminous coal ashes seem promising in the analysis of the occurrence of selected critical elements. The microanalysis has shown that ashes, in addition to enamel of the cenosphere and plerosphere, also contain iron oxides and spinels. These minerals are locally enriched in $\mathrm{Cr}, \mathrm{Cu}, \mathrm{Mn}, \mathrm{Ni}, \mathrm{W}$, and $\mathrm{Zn}$. In the examined samples of microspheres, the iron content is definitely greater than the Clarke value in the Earth's crust. Ferromagnetic microspheres, due to their strong magnetic properties, seem to 
be quite easy to separate. It is estimated that about 7.5 million $\mathrm{Mg}(\mathrm{t})$ of fly ash is captured annually in Poland, so, theoretically, it would be possible to obtain from about 0.6 to 2.9 million tonnes of ferrous aggregates from fly ashes in order to recover supercritical elements.

\section{Acknowledgements}

This study was supported by Statutory Research No 11.11.140.320.

\section{References}

1. V.V. Seredin, R.B. Finkelman, Int. J. Coal. Geol. 70 253-289 (2008)

2. M.P. Ketris, Y.E. Yudovitch, Int. J. Coal. Geol. 78 135-148 (2009)

3. J.C. Hower, S. Dai, V.V. Seredin, L. Zhao, I.J. Kostova, L.F.O. SilvaCoal Combust Gasificat Prod. 5 39-47 (2013)

4. R. Blissett, N. Smalley, B. Rowson, Fuel 119 236-239 (2014)

5. I. Jonczy, J. Nowak, A. Porszke, E. Strzałkowska, Składniki fazowe wybranych mineralnych surowców odpadowych w obrazach mikroskopowych (Eds. Politechniki Śląskiej, Gliwice. 2012)

6. B.G. Kutchko, A.G. Kim, Fuel 85, 2537-2544 (2006)

7. V.B Fenelonov, M.S. Melgunov, V.N. Parmon, KONA Powder and Particle Journal 28 (2010)

8 G.L. Fisher, D.P.Y. Chang, M. Brummer, Science 192, 553-557 (1976)

9. B. Roga, K. Tomków, Chemiczna technologia węgla, (WNT, 1971)

10. A.B. Ronov, Sedimentary Shell of the Earth. (Nauka, Moscow. "Science" Pub. House, 1980)

11. F. Goodarzi, Fuel 85 273-280 (2006)

12. I. Bojakowska, D. Lech, Biul. PIG 448 209-214 (2012)

13. M. Wagner, J. Janczyszyn, Badania ulatniania się pierwiastków śladowych $w$ trakcie procesu spalania węgla brunatnego z aktualnie eksploatowanych złóż węgla, (Arch. ZGZW AGH, Inst. Fizyki AGH i ZGO AGH. 1995) 